\title{
The Impact of Nurse Practitioners on Hospitalizations and Discharges from Long-term Nursing Facilities: A Systematic Review
}

\author{
Michael Mileski ${ }^{1, *} \mathbb{D}$, Upwinder Pannu ${ }^{1}\left(\mathbb{D}\right.$, Bobbi Payne ${ }^{1}$, Erica Sterling ${ }^{1}$ and Rebecca McClay ${ }^{2}$ \\ 1 School of Health Administration, Texas State University, San Marcos, TX 78666, USA; \\ upwinder88@gmail.com (U.P.); bobbi56@msn.com (B.P.); sozostitches@gmail.com (E.S.) \\ 2 School of Science, Technology, Engineering, and Mathematics, American Public University System, \\ Charles Town, WV 25414, USA; rebecca.mcclay@gmail.com \\ * Correspondence: mileski@txstate.edu
}

Received: 20 March 2020; Accepted: 24 April 2020; Published: 28 April 2020

\begin{abstract}
The objective of this study was to increase the understanding of the role a nurse practitioner (NP) has in reducing the risk of hospitalizations and improving quality outcomes among nursing facility residents. This was explored by the research team conducting a systematic literature review via Cumulative Index of Nursing and Allied Health Literature, PubMed (MEDLINE), and Academic Search Ultimate. This is of concern because of the increased rate of hospital readmissions from skilled nursing facilities. The study found that utilization of NPs as primary care providers resulted in decreased unnecessary hospitalizations, increased access to healthcare, and improved health outcomes. NPs are fundamental in building relationships with residents and families and providing them information for decision making. The utilization of NPs in a long-term care setting should be encouraged to improve access to care, decrease hospitalizations, and enhance quality of care. States with reduced or restrictive scope of practice for NPs should revisit the regulations to provide unrestricted scope of practice for NPs.
\end{abstract}

Keywords: nurse practitioner; hospitalization; long-term care; skilled nursing facility; nursing home; resident care; quality of care; quality outcomes

\section{Introduction}

Nurse Practitioners (NPs) are trained to provide primary care in multiple settings including adult, family, pediatric heath, women's health, and gerontology. NPs play a variety of roles in the long-term care setting to include providing both acute and primary care to short-term and long-term care residents, staff consultation on patient issues, and education to residents, families, and staff [1]. Primary services provided by NPs have been found to provide equivalent or more effective chronic disease management in treatment of hypertension, diabetes, depression, and congestive heart failure, than physicians [1,2]. Improved outcomes were noted in functional status of residents with NPs as primary care providers [1]. Nursing facilities with NPs were found to have lower hospitalization rates for diagnoses such as congestive heart failure, chronic obstructive pulmonary disease, hypertension, asthma, and diabetes $[1,3,4]$. The odds of ambulatory care sensitive hospitalization were $43 \%$ lower and $50 \%$ lower in Alzheimer's disease or dementia-related diagnoses in facilities with an onsite NP $[1,4,5]$. Decreased hospitalization results in reducing the cost of care [1,4]. NPs provided a timelier response, spent more time with residents, and conducted more comprehensive assessments than physicians [1]. Onsite NPs improved staff morale, resident satisfaction, and family satisfaction $[1,4,5]$. 


\subsection{Background}

Nursing homes are a vital element of the long-term care system. They play an important role in caring for the most sick, frail, and vulnerable elderly adults. The United States Census Bureau has projected that by 2050, the number of Americans aged 85 years and older will be approximately 19 million [2]. Nursing facilities provide services to meet the medical and psychosocial needs of residents. They also are expected to provide high standards for quality of care and quality of life. Quality of care and quality of life include effectively managing transitional care. Transitional care is coordinating continuity of care to other healthcare facilities or back to the community [3]. The transfer of a resident to a hospital is an example of transitional care.

Nursing home residents are at higher risk for hospitalizations [3,4]. One-fifth of all Medicare beneficiaries were reported to be readmitted to the hospital within 30 days of discharge [3]. It is estimated that $90 \%$ of these hospitalizations were unplanned and cost Medicare approximately $\$ 17.4$ billion [4]. Many of the rehospitalizations were considered to be preventable such as rehospitalizations secondary to congestive heart failure (CHF), respiratory infections, urinary tract infections (UTI), sepsis, and electrolyte imbalance $[4,5]$. Hospitalizations due to the five aforementioned conditions accounted for $78 \%$ of potentially avoidable thirty-day skilled nursing facility rehospitalizations [4]. It is estimated that potentially avoidable rehospitalizations from a skilled nursing facility cost Medicare $\$ 3.39$ billion in 2004 [4]. It is reported that one in six nursing home residents have a hospital admission within any given six-month period [5]. Approximately $40 \%$ of the long-term care residents have a hospital transfer within 30 days prior to their deaths [5]. Some of the causes of preventable hospital readmissions include inadequate management of chronic conditions, inadequate management of infections, and other unplanned events [1,4].

\subsection{Significance}

The diagnostic-related group (DRGs) payment system in hospitals has resulted in shorter hospital length of stays $[1,3,4]$. It has resulted in hospitals discharging patients "quicker and sicker" to nursing facilities [1]. The increase in the number of nursing home residents with clinically complex needs poses a challenge for facilities and physicians to meet them [1,4]. The addition of NPs to the clinical staff can help meet resident needs, provide quality of care, and reduce hospitalizations [1].

The main objective of this literature review is to investigate the role of an NP in reducing hospitalizations and improving quality outcomes in long-term care settings. The study will identify both areas for successes and barriers with the role of the NP.

\section{Materials and Methods}

\subsection{Design}

This study used a systematic review of peer-reviewed articles found in three research databases, Academic Search Ultimate (ASU), CINAHL Complete, and PubMed. The benchmark of acceptability for the topic and Boolean search was no less than 30 unduplicated articles from the three research databases. Using a 4-string Boolean phrase, each author searched for articles pertaining to the research question. This study used terms outside normal MeSH terms, as we were able to realize a much richer base of articles when we utilized different terms for our Boolean search. The initial search was conducted on 22 September 2019. Upon reviewing the articles found during the initial search, the authors used cited articles from the reference lists which led to additional articles meeting the inclusion criteria. The final articles were found on 19 October 2019, completing the search for data needed for the systematic review. The Preferred Reporting Items for Systematic Reviews (PRISMA) guidelines were used to ensure consistent and precise reporting of search results. This review was also constructed and conceptualized using the Kruse Protocol for writing systematic reviews [6]. 


\subsection{Inclusion Criteria}

All authors individually reviewed the articles from the searches. Articles were eligible for inclusion if they were published by academic journals or universities between 1 January 2004 and 30 August 2019. The articles had to be published in the English language and pertaining to humans only. Articles had to explore nurse practitioners impacting hospital admissions or readmissions for patients in long-term care to be included in the systematic review.

\subsection{Exclusion Criteria}

Articles were only incorporated if deemed germane by all authors. Articles that were systematic reviews, literature reviews, or metanalyses were excluded. Articles that pertained to nurse practitioners in acute care were not included. Analysis of projected proposed use of nurse practitioners or conceptual models were excluded. The review did not include comparisons of physicians to nurse practitioners in relation to hospital readmissions. Bias was not considered when reviewing the research involved in this study. The final sample of articles after meeting exclusion criteria was then analyzed further for consensus among all authors for final inclusion. When analyzed, the sample yielded a kappa statistic $(\mathrm{k}=1)$, showing strong reliability.

\section{Results}

\subsection{Study Selection}

The article selection process is outlined in the PRISMA flow diagram in Figure 1. The initial search protocol identified a total of 65 articles from the three databases. Eleven articles were excluded when articles were filtered to include English and humans only, published between 1 January 2004 and 31 December 2019. Researchers chose to extend the search parameters to fifteen years due to a lack of relevant research in the field. Forty-two articles remained and 28 duplicates articles were removed leaving a total of 14 articles. Upon reviewing the articles found during the initial search, the authors used cited articles from the references lists which led to additional 16 germane articles. The total number of articles for the systematic review was 30.

PubMed (MEDLINE)
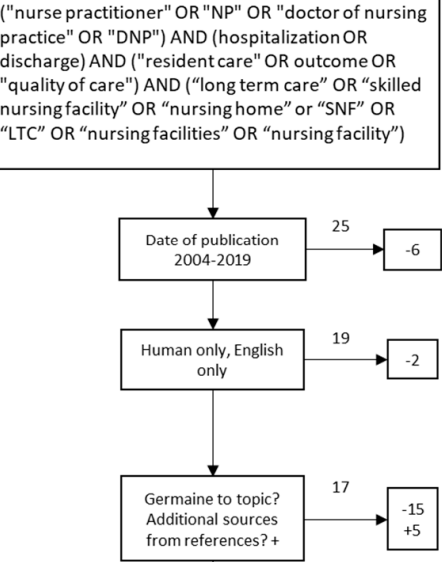
m refer

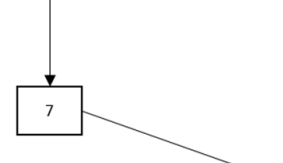

CINAH \begin{tabular}{|l|}
\hline \\
("nurse practitioner" OR "NP" OR "doctor of nursing \\
practice" OR "DNP") AND (hospitalization OR \\
discharge) AND ("resident care" OR outcome OR \\
"quality of care") AND ("long term care" OR "skilled \\
nursing facility" OR "nursing home" or "SNF" OR \\
"LTC" OR "nursing facilities" OR "nursing facility")
\end{tabular}

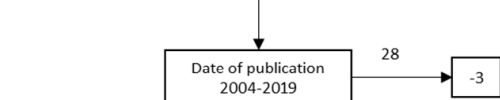
2004-2019

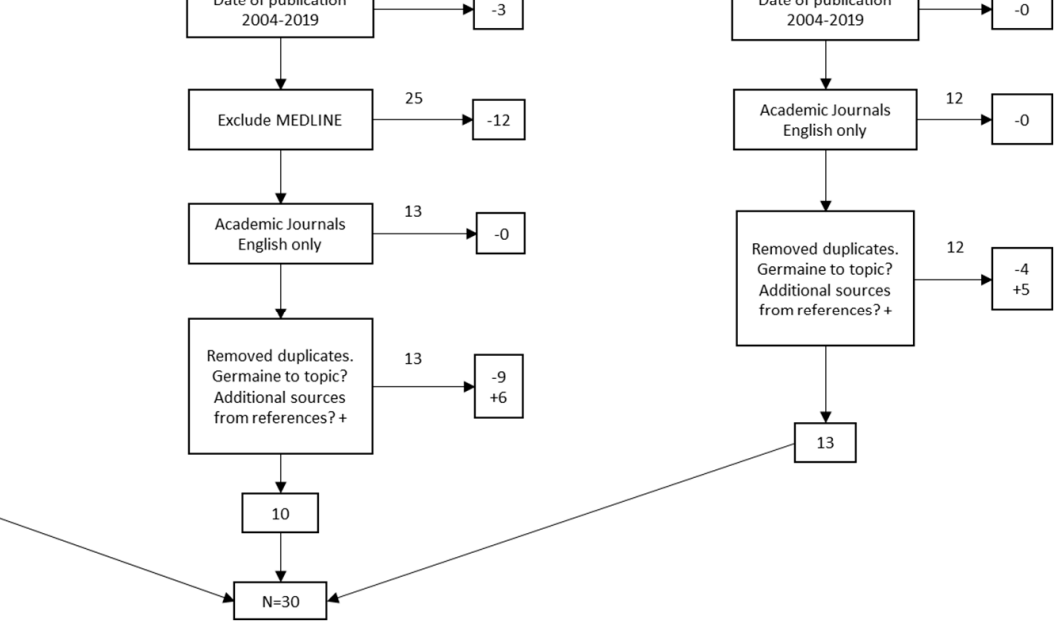

Academic Search Ultimate

("nurse practitioner" OR "NP" OR "doctor of nursing practice" OR "DNP") AND (hospitalization R discharge) AND ("resident care "OR outcom RR "quality of care") AND ("long term care" OR "skilled nursing facility" OR "nursing home" or "SNF" OR “LTC" OR "nursing facilities" OR “nursing facility")

Figure 1. Preferred Reporting Items for Systematic Reviews Flow Diagram (PRISMA). 


\subsection{Assessment Tools}

The 30 articles selected for the systematic review were summarized to include the author, aim, setting, methods, assessment tool, and key findings. The summary of articles is listed in Table 1. The authors examined and analyzed the 30 selected articles, identified facilitator and barrier themes, and then sorted the articles according to their respective facilitator or barrier theme. Using the Affinity Matrix, facilitator and barrier themes associated with NPs reducing hospitalizations and improving quality outcomes in long-term care settings were listed by frequency of occurrences using articles numbers. The sum and percentages of the frequencies of facilitator and barrier themes were then calculated. The Affinity Matrix diagram is demonstrated in Table 2. 
Table 1. Studies selected for review and a summary of design, methods, and results.

\begin{tabular}{|c|c|c|c|c|c|}
\hline $\begin{array}{l}\text { Author Last } \\
\text { Name }\end{array}$ & Aim & Sample/Settings & Method & Assessment Tool & Key Findings \\
\hline Popejoy & $\begin{array}{l}\text { Exploring the differences in } \\
\text { potentially } \\
\text { avoidable/unavoidable hospital } \\
\text { transfers in a retrospective } \\
\text { analysis of INTERACT } \\
\text { (Interventions to Reduce Acute } \\
\text { Care Transfers, ACTs (Acute } \\
\text { Transfer Tools) completed by } \\
\text { advanced practice registered } \\
\text { nurses (APRNs) working in the } \\
\text { Missouri Quality Improvement } \\
\text { Initiative (MOQI) }\end{array}$ & $\begin{array}{l}16 \text { nursing homes, } \\
\text { ranging from } 120 \text { to } 321 \\
\text { beds }\end{array}$ & $\begin{array}{l}\text { Cross-sectional descriptive } \\
\text { study }\end{array}$ & INTERACT and ACT & $\begin{array}{l}\text { Over one-half of the transfers ( } 54 \%) \\
\text { were identified as avoidable transfers. } \\
\text { Clinical factors related to avoidable } \\
\text { transfers included falls, fever, urinary } \\
\text { symptoms/incontinence. The } \\
\text { transfers had a condition which } \\
\text { could have been managed in a } \\
\text { nursing home }(58 \%) \text {, transfers could } \\
\text { have been avoided with better } \\
\text { communication ( } 39 \%) \text {, new } \\
\text { signs/symptoms detected earlier } \\
(31 \%) \text {, and advance directives in } \\
\text { place earlier }(11 \%)\end{array}$ \\
\hline $\begin{array}{l}\text { Ouslander, } \\
\text { Naharci }\end{array}$ & $\begin{array}{l}\text { To determine the types of SNF to } \\
\text { hospital transfers that occur } \\
\text { within } 48 \mathrm{~h} \text { and } 30 \text { days of SNF } \\
\text { admission based on root cause } \\
\text { analyses (RCAs) and to identify } \\
\text { potential areas for improving } \\
\text { transitional care between } \\
\text { hospitals and SNFs }\end{array}$ & 88 skilled nursing facilities & $\begin{array}{l}\text { Trained staff from SNFs } \\
\text { enrolled in a randomized, } \\
\text { controlled clinical trial of the } \\
\text { INTERACT (Interventions to } \\
\text { Reduce Acute Care Transfers) } \\
\text { quality improvement program } \\
\text { performed retrospective RCAs } \\
\text { on hospital transfers during a } \\
\text { 12-month implementation } \\
\text { period }\end{array}$ & $\begin{array}{l}\text { INTERACT (Interventions to } \\
\text { Reduce Acute Care Transfers) } \\
\text { Quality Improvement (QI) } \\
\text { tool, retrospective RCA (root } \\
\text { cause analyses) on hospital } \\
\text { transfers }\end{array}$ & $\begin{array}{l}\text { First, more intensive monitoring of } \\
\text { these patients during the first } 48 \mathrm{~h} \text { to } \\
7 \text { days after SNF admission may help } \\
\text { identify changes in condition early } \\
\text { enough to intervene before hospital } \\
\text { transfer is necessary. Teams of } \\
\text { physicians and nurse practitioners } \\
\text { have been shown to be effective in } \\
\text { reducing hospitalizations and } \\
\text { potentially avoidable hospitalizations } \\
\text { in particular }\end{array}$ \\
\hline Bethea & $\begin{array}{l}\text { To compare the outcomes in } \\
\text { elderly patients whose care was } \\
\text { coordinated by trauma nurse } \\
\text { practitioner (TNP) versus non } \\
\text { trauma NP (NTNP) }\end{array}$ & $\begin{array}{l}1363 \text { patients were } \\
\text { analyzed for this study in } \\
\text { a Level } 1 \text { trauma center } \\
\text { between December } 2014 \\
\text { and June } 2017\end{array}$ & Retrospective cohort study & $\begin{array}{l}\text { Patient demographics, } \\
\text { comorbidities, admission } \\
\text { injuries, Injury Severity Score } \\
\text { (ISS), hospital length of stay } \\
\text { and unplanned ICU } \\
\text { admission. Study outcomes } \\
\text { also based on discharge } \\
\text { location including home, } \\
\text { skilled nursing, in-hospital } \\
\text { mortality, 30-day readmission } \\
\text { and hospital charges }\end{array}$ & $\begin{array}{l}\text { Shorter length of stay for patients } \\
\text { under care of TNPs which resulted in } \\
\text { decreased hospital charges of } \$ 13,000 \\
\text { per admission. Patient under care of } \\
\text { TNPs demonstrated higher } \\
\text { percentage of home discharges as } \\
\text { compared to discharge to skilled } \\
\text { nursing facilities }\end{array}$ \\
\hline
\end{tabular}


Table 1. Cont

\begin{tabular}{|c|c|c|c|c|c|}
\hline $\begin{array}{l}\text { Author Last } \\
\text { Name }\end{array}$ & Aim & Sample/Settings & Method & Assessment Tool & Key Findings \\
\hline Rantz, Popejoy & $\begin{array}{l}\text { To determine if the Missouri } \\
\text { Quality Initiative (MOQI) for } \\
\text { long-stay nursing home residents } \\
\text { reduced the frequency of } \\
\text { preventable hospitalizations, } \\
\text { improved resident health } \\
\text { outcomes, improved the process } \\
\text { of transition of care between } \\
\text { hospitals and nursing facilities } \\
\text { and reduced healthcare costs }\end{array}$ & $\begin{array}{l}16 \text { nursing homes in } \\
\text { metro, urban and rural } \\
\text { communities }\end{array}$ & $\begin{array}{l}\text { Prospective, single group } \\
\text { intervention design }\end{array}$ & $\begin{array}{l}\text { Interventions to Reduce } \\
\text { Acute Care Transfers } \\
\text { (INTERACT), INTERACT } \\
\text { RCA (Root Cause Analysis), } \\
\text { Early illness identification } \\
\text { (stop and watch), SBAR } \\
\text { (Situation, background, } \\
\text { assessment, recommendation) }\end{array}$ & $\begin{array}{l}\text { The MOQI (Missouri Quality Initiative) } \\
\text { achieved } 30 \% \text { reduction in all-cause } \\
\text { hospitalizations with full-time APRNs } \\
\text { working in each facility and supported } \\
\text { by the MOQI team to assist with } \\
\text { quality improvement activities, } \\
\text { consistent use of INTERACT, increased } \\
\text { end-of-life decision making, and } \\
\text { improved use of HIT (health } \\
\text { information technology) for secure } \\
\text { communication. There was a decline in } \\
\text { the nonavoidable transfers from } 64 \% \text { to } \\
47 \% \text { and an increase in the percentage } \\
\text { of avoidable from } 47 \% \text { to } 54 \%\end{array}$ \\
\hline Rantz, Birtley & $\begin{array}{l}\text { To study the implementation of } \\
\text { an inter-professional model in } \\
\text { nursing facilities with advanced } \\
\text { practice registered nurses } \\
\text { (APRNs) with aim to reduce } \\
\text { preventable hospitalizations } \\
\text { among nursing home residents }\end{array}$ & $\begin{array}{l}16 \text { nursing homes. SNF, } \\
\text { LTC }\end{array}$ & $\begin{array}{l}\text { Retrospective, } \\
\text { quasi-experimental }\end{array}$ & $\begin{array}{l}\text { Physician and APRN } \\
\text { reimbursement by CPT codes. } \\
\text { Allowable APRN visits and } \\
\text { orders for SNF versus NF }\end{array}$ & $\begin{array}{l}\text { The model results demonstrated } \\
\text { significant reduction in } \\
\text { hospitalizations ( } 40 \% \text { all cause, } 58 \% \\
\text { potentially avoidable), emergency } \\
\text { room visits ( } 54 \% \text { all cause, } 65 \% \\
\text { potentially avoidable), Medicare } \\
\text { expenditures for hospitalizations ( } 34 \% \\
\text { all cause, } 45 \% \text { potentially avoidable), } \\
\text { and Medicare expenditures for } \\
\text { emergency room visits ( } 50 \% \text { all cause, } \\
60 \% \text { potentially avoidable) }\end{array}$ \\
\hline Ersek & $\begin{array}{l}\text { To reduce the burden of costly } \\
\text { hospitalizations of nursing home } \\
\text { residents by using the } \\
\text { Transforming Institutional Care } \\
\text { Project (OPTIMISTIC) }\end{array}$ & $\begin{array}{l}19 \text { skilled nursing } \\
\text { facilities. Participants } \\
\text { included } 23 \text { nursing home } \\
\text { staff and leaders, } 4 \\
\text { primary care providers, } 10 \\
\text { family members, and } 26 \\
\text { OPTIMISTIC clinical staff }\end{array}$ & $\begin{array}{l}\text { One time, semi structured } \\
\text { qualitative interviews }\end{array}$ & $\begin{array}{l}\text { Advance care planning (ACP), } \\
\text { Transforming Institutional } \\
\text { Care (OPTIMISTIC), } \\
\text { INTERACT }\end{array}$ & $\begin{array}{l}\text { This project provided NPs time to } \\
\text { facilitate high quality ACP discussions, } \\
\text { conduct comprehensive resident } \\
\text { assessment, timely identification and } \\
\text { management of acute changes, staff } \\
\text { education, thorough discussions with } \\
\text { residents and families regarding care } \\
\text { plan goals and analysis of root causes } \\
\text { for potentially preventable } \\
\text { hospitalizations }\end{array}$ \\
\hline
\end{tabular}


Table 1. Cont

\begin{tabular}{|c|c|c|c|c|c|}
\hline $\begin{array}{l}\text { Author Last } \\
\text { Name }\end{array}$ & Aim & Sample/Settings & Method & Assessment Tool & Key Findings \\
\hline Yang & $\begin{array}{l}\text { To determine which clinical } \\
\text { specialties are most significant to } \\
\text { care of individuals with dementia } \\
\text { in the community and long-term } \\
\text { care (LTC) settings }\end{array}$ & $\begin{array}{l}\text { Long term care setting } \\
\text { and Community setting. } \\
\text { Fee-for-service Medicare } \\
\text { beneficiaries with } \\
\text { dementia aged } 65 \text { years or } \\
\text { older }\end{array}$ & Cross-sectional analysis & $\begin{array}{l}\text { Patient characteristics were } \\
\text { examined by specialty of the } \\
\text { PPC (predominant provider } \\
\text { of care) and by community } \\
\text { versus LTC settings using t } \\
\text { test or chi-squared tests, as } \\
\text { appropriate. The maps were } \\
\text { used to show geographic } \\
\text { variation at the state level for } \\
\text { NPs as the PPC of care }\end{array}$ & $\begin{array}{l}\text { More than } 90 \% \text { of beneficiaries had } \\
\text { primary care providers as their PPC in } \\
\text { LTC compared with } 77.3 \% \text { of } \\
\text { beneficiaries in the community. Among } \\
\text { the primary care providers, NPs as } \\
\text { PPCs had the greatest difference } \\
\text { between community }(6.9 \%) \text { and LTC } \\
(19.2 \%) \text {. NPs play as PPCs in LTC and } \\
\text { how their role differs across states. In } \\
\text { LTC, } 40 \text { states had NPs serving as PPCs } \\
\text { for } 12 \% \text { to } 40 \% \text { of dementia } \\
\text { beneficiaries living in LTC facilities }\end{array}$ \\
\hline Meunier & $\begin{array}{l}\text { The research determines if the } \\
\text { use of comprehensive models, } \\
\text { such as Program of All-Inclusive } \\
\text { Care for the Elderly (PACE), lead } \\
\text { to improved functional outcomes } \\
\text { for participants and cost savings } \\
\text { through decreased utilization }\end{array}$ & $\begin{array}{l}\text { Long term care in } \\
\text { community setting. } 34 \\
\text { former participants in } \\
\text { PACE were monitored } \\
\text { every } 6 \text { months for } 2 \text { years } \\
\text { and data was collected }\end{array}$ & $\begin{array}{l}\text { Retrospective, } \\
\text { quasi-experimental }\end{array}$ & $\begin{array}{l}\text { Physical Self-Maintenance } \\
\text { Scale, Instrumental Activities } \\
\text { of Daily Living Scale, 6-point } \\
\text { Likert response scale, Saint } \\
\text { Louis University Mental } \\
\text { Status Exam (SLUMS) }\end{array}$ & $\begin{array}{l}\text { Both number of ED visits and } \\
\text { hospitalizations were found to be } \\
\text { significantly higher after PACE closure. } \\
\text { For every hour of home health per } \\
\text { month, the number of ED/hospital } \\
\text { visits decreased in a 6-month period by } \\
5.4 \% \text {. Over the 2-year study period, } \\
\text { functional scores ADLs and IADLs } \\
\text { significantly declined. The majority of } \\
\text { participants ( } 67 \% \text { ) reported a higher } \\
\text { level of satisfaction with PACE services } \\
\text { as compared to usual care provided } \\
\text { post-PACE }\end{array}$ \\
\hline Oliver & $\begin{array}{l}\text { To examine the relationship } \\
\text { between the level of advanced } \\
\text { practice registered nurse (APRN) } \\
\text { practice (full, reduced, or } \\
\text { restricted) allowed and results of } \\
\text { analyses of Medicare or } \\
\text { Medicare-Medicaid beneficiaries } \\
\text { of possibly preventable } \\
\text { hospitalizations, readmission } \\
\text { rates after inpatient rehabilitation, } \\
\text { and nursing home resident } \\
\text { hospitalizations }\end{array}$ & $\begin{array}{l}\text { Hospitals, Inpatient rehab, } \\
\text { SNF and LTC }\end{array}$ & Retrospective & $\begin{array}{l}\text { Two-sampled t-tests, } \\
\text { One-way analysis of variance, } \\
\text { Tukey test }\end{array}$ & $\begin{array}{l}\text { States with the highest level of scope of } \\
\text { practice for NPs showed reduced } \\
\text { hospitalizations and enhanced health } \\
\text { outcomes. The study indicates that any } \\
\text { type of barriers which restrict NPs to } \\
\text { practice within their full scope is } \\
\text { inversely related to the positive effect } \\
\text { on hospitalizations and state health } \\
\text { outcomes }\end{array}$ \\
\hline
\end{tabular}


Table 1. Cont.

\begin{tabular}{|c|c|c|c|c|c|}
\hline $\begin{array}{l}\text { Author Last } \\
\text { Name }\end{array}$ & Aim & Sample/Settings & Method & Assessment Tool & Key Findings \\
\hline Segal & $\begin{array}{l}\text { To examine potentially } \\
\text { preventable hospitalizations rates } \\
\text { by setting, state, medical } \\
\text { condition, and cost }\end{array}$ & $\begin{array}{l}\text { Hospital, Inpatient rehab, } \\
\text { SNF, LTC, home health } \\
\text { and community }\end{array}$ & Retrospective & $\begin{array}{l}\text { Potentially Avoidable } \\
\text { Hospitalization Algorithm, } \\
\text { ICD-9 diagnosis }\end{array}$ & $\begin{array}{l}\text { The national rate among MMEs for } \\
\text { potentially avoidable hospitalizations } \\
\text { was } 133 \text { per } 1000 \text { person-years, but } \\
\text { there was considerable variation across } \\
\text { health care settings. For those MMEs } \\
\text { receiving care in a skilled nursing } \\
\text { facility, the potentially avoidable } \\
\text { hospitalizations rate was } 690 \text { per } 1000 \\
\text { person-years. Five conditions were } \\
\text { responsible for nearly } 80 \text { percent of } \\
\text { potentially avoidable hospitalizations } \\
\text { occurring among the study population: } \\
\text { congestive heart failure ( }(21 \%), \\
\text { COPD/asthma }(20 \%), \text { urinary tract } \\
\text { infections }(15 \%) \text { pneumonia (13\%), } \\
\text { and dehydration }(11 \%)\end{array}$ \\
\hline $\begin{array}{l}\text { Anderson and } \\
\text { Ferguson }\end{array}$ & $\begin{array}{l}\text { Reduce hospital readmissions by } \\
\text { an NP completing a systematic } \\
\text { medication reconciliation process } \\
\text { for all new admissions }\end{array}$ & $\begin{array}{l}\text { 90-bed skilled nursing } \\
\text { facility }\end{array}$ & $\begin{array}{l}\text { Pre- and } \\
\text { postimplementation } \\
\text { design }\end{array}$ & $\begin{array}{l}\text { Evidence-based workflow } \\
\text { process, chi-square analysis }\end{array}$ & $\begin{array}{l}19.2 \% \text { hospital readmission rate pre } \\
\text { implementation and } 13.5 \% \\
\text { postimplementation, a } 29.7 \% \text { decrease } \\
\text { in hospitalizations within a } 30 \text {-day } \\
\text { period }\end{array}$ \\
\hline Ingber & $\begin{array}{l}\text { Improve the overall health and } \\
\text { health care of participating } \\
\text { long-stay residents of nursing } \\
\text { facilities, reducing potentially } \\
\text { avoidable hospitalizations, } \\
\text { improving quality of care, and } \\
\text { decreasing health care spending }\end{array}$ & $\begin{array}{l}\text { Long-stay residents-total } \\
\text { of } 143 \text { nursing facilities }\end{array}$ & $\begin{array}{l}\text { Mixed methods, } \\
\text { quantitative and } \\
\text { qualitative analysis, } \\
\text { multivariate regression }\end{array}$ & $\begin{array}{l}\text { Analysis of claims and } \\
\text { assessments, site visits, } \\
\text { interviews, and surveys }\end{array}$ & $\begin{array}{l}\text { Multipronged NP interventions reduce } \\
\text { potentially avoidable hospitalizations } \\
\text { and related Medicare expenditures }\end{array}$ \\
\hline Kane & $\begin{array}{l}\text { Assess the quality of care using } \\
\text { Evercare approach which } \\
\text { employs NPs to provide } \\
\text { additional primary care over and } \\
\text { above that provided by } \\
\text { physicians }\end{array}$ & Nursing home residents & Experimental & $\begin{array}{l}\text { Data from MDS, Medicare, } \\
\text { and United Healthcare, } \\
\text { survival analysis, risk } \\
\text { adjustment methods applied } \\
\text { to the quality indicators }\end{array}$ & $\begin{array}{l}\text { Hazard rates significantly lower for } \\
\text { Evercare residents, residents had fewer } \\
\text { preventable hospitalizations }\end{array}$ \\
\hline
\end{tabular}


Table 1. Cont.

\begin{tabular}{|c|c|c|c|c|c|}
\hline $\begin{array}{l}\text { Author Last } \\
\text { Name }\end{array}$ & Aim & Sample/Settings & Method & Assessment Tool & Key Findings \\
\hline Krichbum & $\begin{array}{l}\text { Test effectiveness of nursing } \\
\text { intervention model to improve } \\
\text { health function, and return-home } \\
\text { outcomes using a gerontological } \\
\text { advanced practice nurse (GAPN) } \\
\text { to provide interventions } 6 \\
\text { months post-acute care, making } \\
\text { biweekly visits and/or phone calls }\end{array}$ & $\begin{array}{l}33 \text { elders } 65 \text { years and } \\
\text { older with a hip fracture }\end{array}$ & Randomized clinical trial & $\begin{array}{l}\text { Mini Mental Status Exam } \\
\text { (MMSE), Global (GH) } \\
\text { self-ratings, Geriatric } \\
\text { Depression Scale (GDS), } \\
\text { Functional Status Index (FSI) } \\
\text { and listing of living situation }\end{array}$ & $\begin{array}{l}\text { Improved function in mobility, home } \\
\text { chores, and personal care activities }\end{array}$ \\
\hline Ploeg & $\begin{array}{l}\text { Report the perceptions of } \\
\text { residents and family members } \\
\text { about the role of the nurse } \\
\text { practitioner in long term care } \\
\text { settings }\end{array}$ & $\begin{array}{l}35 \text { residents and family } \\
\text { members from four } \\
\text { long-term care settings } \\
\text { that employed a nurse } \\
\text { practitioner }\end{array}$ & $\begin{array}{l}\text { Qualitative descriptive } \\
\text { approach, individual and } \\
\text { focus groups interviews }\end{array}$ & $\begin{array}{l}\text { Conventional content analysis } \\
\text { was used to identify themes } \\
\text { and subthemes }\end{array}$ & $\begin{array}{l}\text { Perceptions of residents and family } \\
\text { members of the nurse practitioner role } \\
\text { in long-term care setting consistent } \\
\text { with person-centered and } \\
\text { relationship-centered care, enhanced } \\
\text { quality of care, positive care experience }\end{array}$ \\
\hline Poghosyan & $\begin{array}{l}\text { Determine the impact of state and } \\
\text { organizations on nurse } \\
\text { practitioner practice environment }\end{array}$ & $\begin{array}{l}291 \text { nurse practitioners in } \\
\text { MA and } 278 \text { nurse } \\
\text { practitioners in NY }\end{array}$ & $\begin{array}{l}\text { Cross-sectional survey } \\
\text { design; online surveys }\end{array}$ & $\begin{array}{l}\text { Nurse Practitioner Primary } \\
\text { Care Organizational Climate } \\
\text { Questionnaire }\end{array}$ & $\begin{array}{l}\text { NPs have positive perceptions of their } \\
\text { relationship with physicians, NP's } \\
\text { perceptions of the relationships they } \\
\text { have with administration is deficient, } \\
\text { state and organizational policies } \\
\text { should be taken into consideration to } \\
\text { ensure least restrictive practice }\end{array}$ \\
\hline Rantz & $\begin{array}{l}\text { Review impact of advance } \\
\text { practice registered nurses } \\
\text { (APRNs) on the quality measure } \\
\text { scores of } 16 \text { nursing homes } \\
\text { participating the Missouri Quality } \\
\text { Initiative (MOQI) intervention }\end{array}$ & 16 nursing homes & Two-group comparisons & $\begin{array}{l}\text { Data was collected for } 36 \\
\text { months and analysis of } \\
\text { results conducted to create a } \\
\text { composite quality measure } \\
\text { score for each facility, } \\
\text { Interventions to Reduce } \\
\text { Acute Care Transfers } \\
\text { (INTERACT) using the Stop } \\
\text { and Watch and Situation, } \\
\text { Background, Assessment, } \\
\text { Recommendation (SBAR) }\end{array}$ & $\begin{array}{l}\text { APRNs working full-time in nursing } \\
\text { homes positively influenced quality of } \\
\text { care, reduced unnecessary } \\
\text { hospitalizations and emergency room } \\
\text { transfers, improved the process of } \\
\text { transitioning between inpatient } \\
\text { hospitals and nursing facilities, and } \\
\text { reduced overall healthcare spending } \\
\text { without restricting access to care }\end{array}$ \\
\hline
\end{tabular}


Table 1. Cont.

\begin{tabular}{|c|c|c|c|c|c|}
\hline $\begin{array}{l}\text { Author Last } \\
\text { Name }\end{array}$ & Aim & Sample/Settings & Method & Assessment Tool & Key Findings \\
\hline Rosenfeld & $\begin{array}{l}\text { Determine the national practice } \\
\text { patterns of nurse practitioners } \\
\text { providing care in long-term care } \\
\text { facilities }\end{array}$ & $\begin{array}{l}\text { All physicians who are } \\
\text { members of the American } \\
\text { Medical Directors } \\
\text { Association (AMDA) }\end{array}$ & Mailed survey & $\begin{array}{l}\text { The survey mailed out included } \\
\text { six domains: (1) the number of } \\
\text { LTC facilities that have NPs } \\
\text { involved in providing care; (2) } \\
\text { the number of NPs engaged in } \\
\text { care at these facilities; (3) the } \\
\text { types of employment/financial } \\
\text { arrangements between NPs and } \\
\text { LTC facilities; (4) the types of } \\
\text { services provided by the NPs; (5) } \\
\text { the effectiveness of the NPs as } \\
\text { perceived by the medical director; } \\
\text { and (6) the perceived future } \\
\text { demand for NPs in LTC }\end{array}$ & $\begin{array}{l}\text { NPs involved in LTC are more likely to } \\
\text { be involved in facilities with } 100+\text { beds, } \\
\text { performed a wide range of services, are } \\
\text { effective at maintaining physician, } \\
\text { resident, and family satisfaction, were } \\
\text { highly effective with regard to } \\
\text { emergency room transfers, increasing } \\
\text { the quality of care, survey } \\
\text { preparedness, and hospital admissions. } \\
\text { Respondents to the survey were } \\
\text { overwhelmingly positive about } \\
\text { working with NPs }\end{array}$ \\
\hline Ryskina & $\begin{array}{l}\text { Describe current practice } \\
\text { behaviors to identify areas where } \\
\text { interventions could improve } \\
\text { post-acute care outcomes }\end{array}$ & $\begin{array}{l}\text { Fee-for-service Medicare } \\
\text { beneficiaries, 65+ years } \\
\text { old, discharged from an } \\
\text { acute care hospital to a } \\
\text { SNF in the period of } \\
\text { January 2012-October } \\
2014\end{array}$ & Retrospective & $\begin{array}{l}\text { Aggregate data from Medicare } \\
\text { claims January 2012-October } \\
\text { 2014, supplemental information } \\
\text { from MDS and Provider of } \\
\text { Services }\end{array}$ & $\begin{array}{l}\text { Timely access to physicians or NPs } \\
\text { after hospital discharges to a SNF } \\
\text { depends on local practice patterns, not } \\
\text { clinical needs }\end{array}$ \\
\hline Kaasalainen & $\begin{array}{l}\text { To evaluate the level of } \\
\text { involvement of nurse } \\
\text { practitioners (NPs) in activities } \\
\text { related to preventing and } \\
\text { managing fractures in long-term } \\
\text { care (LTC) }\end{array}$ & Long term care (LTC) & $\begin{array}{l}\text { A cross-sectional } \\
\text { survey, qualitative } \\
\text { interviews }\end{array}$ & $\begin{array}{l}\text { The first section focused on } \\
\text { demographic information, the } \\
\text { second section gathered } \\
\text { information on practice patterns } \\
\text { of NPs related to fracture-risk } \\
\text { assessment, post-fracture } \\
\text { management and use of } \\
\text { evidence-based guidelines, the } \\
\text { third section surveyed on the } \\
\text { processes NPs would follow to } \\
\text { respond to related care decisions, } \\
\text { and last section focused on } \\
\text { identification of the barriers and } \\
\text { facilitators faced by NPs to } \\
\text { prevent and manage fractures }\end{array}$ & $\begin{array}{l}\text { The finding suggest that the NP were } \\
\text { involved in caring for residents' post } \\
\text { fractures and in risk factors } \\
\text { assessments. The role of NP in } \\
\text { managing fractures can be optimized } \\
\text { by addressing barriers such as } \\
\text { inadequate staffing at the facility and } \\
\text { lack of timely access to diagnostic } \\
\text { services }\end{array}$ \\
\hline
\end{tabular}


Table 1. Cont.

\begin{tabular}{|c|c|c|c|c|c|}
\hline $\begin{array}{l}\text { Author Last } \\
\text { Name }\end{array}$ & Aim & Sample/Settings & Method & Assessment Tool & Key Findings \\
\hline $\begin{array}{l}\text { Ouslander, } \\
\text { Naharci }\end{array}$ & $\begin{array}{l}\text { To determine if conducting root } \\
\text { cause analyses (RCA) on } \\
\text { transition of residents from } \\
\text { skilled nursing facility to } \\
\text { hospitals can help prevent } \\
\text { preventable emergency } \\
\text { department (ED) visits and } \\
\text { hospitalizations }\end{array}$ & Sixty-four of $88 \mathrm{SNFs}$ & $\begin{array}{l}\text { Retrospective, } \\
\text { quasi-experimental }\end{array}$ & $\begin{array}{l}\text { INTERACT (Interventions to } \\
\text { Reduce Acute Care Transfers), } \\
\text { Quality Improvement (QI) tool }\end{array}$ & $\begin{array}{l}\text { The studies indicate that using RCAs } \\
\text { provides important insights to factors } \\
\text { contributing to the transfers, propose } \\
\text { several areas of attention for process } \\
\text { improvements and related education } \\
\text { which may help reduce preventable } \\
\text { hospitalizations }\end{array}$ \\
\hline Kuo & $\begin{array}{l}\text { The use of nurse practitioners } \\
\text { (NPs) is one way to address the } \\
\text { shortage of physician primary } \\
\text { care providers }\end{array}$ & $\begin{array}{l}\text { Medicare beneficiaries } \\
\text { aged } 65 \text { or older with } \\
\text { Parts A and B coverage } \\
\text { and not in a health } \\
\text { maintenance organization } \\
\text { (HMO) for the entire } \\
\text { twelve months of each } \\
\text { year during 1998-2010 }\end{array}$ & $\begin{array}{l}\text { We identified } \\
\text { individual providers } \\
\text { by their Unique } \\
\text { Provider } \\
\text { Identification } \\
\text { Number for } \\
\text { 1998-2007 and } \\
\text { National Provider } \\
\text { Identifier for } \\
\text { 2007-10 }\end{array}$ & $\begin{array}{l}\text { Hierarchical generalized linear } \\
\text { mixed models }\end{array}$ & $\begin{array}{l}\text { The overall number of NPs reimbursed } \\
\text { for evaluation and management } \\
\text { services in the } 5 \text { percent Medicare } \\
\text { claims data rose from } 3114 \text { in } 1998 \text { to } \\
37,638 \text { in } 2010\end{array}$ \\
\hline Mullaney & $\begin{array}{l}\text { To understand the impact of } \\
\text { mortality risk assessments } \\
\text { (MRAs) and advance care } \\
\text { planning (ACP) discussions } \\
\text { completed by nurse practitioners } \\
\text { (NP) on clinical outcomes for } \\
\text { newly registered Medicare } \\
\text { Advantage nursing home } \\
\text { residents }\end{array}$ & $\begin{array}{l}\text { The final sample of } 87 \\
\text { patients was } 72 \% \text { female } \\
\text { with a mean age of } 81 \\
\text { years, LTC }\end{array}$ & $\begin{array}{l}\text { Prospective, } \\
\text { nonexperimental } \\
\text { approach }\end{array}$ & $\begin{array}{l}\text { Mortality Risk Assessment (MRA) } \\
\text { \& Advance Care Planning (ACP) }\end{array}$ & $\begin{array}{l}\text { The study demonstrated positive } \\
\text { clinical outcomes post ACP discussions. } \\
\text { The outcomes include increase in } \\
\text { number of patients with a comfort goal } \\
\text { of care, decline in full-code status } \\
\text { patients, reduced hospitalizations and } \\
\text { improved quality in end-of-life care }\end{array}$ \\
\hline Cole & $\begin{array}{l}\text { NPs collaborative practice with } \\
\text { physician and nursing colleagues } \\
\text { to reduce hospitalization }\end{array}$ & $\begin{array}{l}\text { 190-bed residential care } \\
\text { facility in New Brunswick, } \\
\text { LTC }\end{array}$ & Retrospective & Daily clinical monitoring & $\begin{array}{l}\text { As shown in this case, the presence of } \\
\text { an NP clearly impacted a reduction in } \\
\text { emergency room visits and } \\
\text { hospitalizations, events that often } \\
\text { accelerate further physical, mental, and } \\
\text { functional decline particularly among } \\
\text { the frail elderly }\end{array}$ \\
\hline
\end{tabular}


Table 1. Cont

\begin{tabular}{|c|c|c|c|c|c|}
\hline $\begin{array}{l}\text { Author Last } \\
\text { Name }\end{array}$ & Aim & Sample/Settings & Method & Assessment Tool & Key Findings \\
\hline Hullick & $\begin{array}{l}\text { To examines the impact of the } \\
\text { aged care emergency services } \\
\text { (ACE) on residential aged care } \\
\text { facilities (RACF) residents' } \\
\text { transfers to hospitals }\end{array}$ & Four RACFs, LTC & $\begin{array}{l}\text { Prospective, } \\
\text { retrospective }\end{array}$ & Generalized estimating equations & $\begin{array}{l}\text { This study has demonstrated that a } \\
\text { complex multi-strategy intervention } \\
\text { led by nursing staff can successfully } \\
\text { reduce hospital admissions for older } \\
\text { people living in Residential Aged Care } \\
\text { Facilities }\end{array}$ \\
\hline Ordonez & $\begin{array}{l}\text { To examine the outcome of a } \\
\text { gerontological nurse practitioner } \\
\text { (GNP) care coordination model } \\
\text { on healthy transition and 30-day } \\
\text { rehospitalizations among older } \\
\text { adults. In this study, the patients } \\
\text { are discharged from a hospital to } \\
\text { a SNF for rehabilitation post } \\
\text { coronary artery bypass graft } \\
\text { (CABG) surgery }\end{array}$ & $\begin{array}{l}10 \text { older adults with age }> \\
65 \text { years status post CABG. } \\
\text { Skilled nursing facility }\end{array}$ & $\begin{array}{l}\text { Retrospective, } \\
\text { quasi-experimental }\end{array}$ & $\begin{array}{l}\text { Scale 1-4 including control of } \\
\text { signs and symptoms, functional } \\
\text { status, depression, sense of } \\
\text { integrity }\end{array}$ & $\begin{array}{l}\text { Findings indicate five to eight percent } \\
\text { more effectiveness in outcomes with } \\
\text { GNP care coordination model than the } \\
\text { standard of care. The project } \\
\text { demonstrates the effectiveness of the } \\
\text { GNP care coordination model in } \\
\text { decreasing the risk of 30-day } \\
\text { rehospitalization and facilitating the } \\
\text { development of realistic and } \\
\text { achievable goals }\end{array}$ \\
\hline Dwyer & $\begin{array}{l}\text { Reducing avoidable } \\
\text { hospitalizations of aged care } \\
\text { facility (ACF) residents can } \\
\text { improve the resident experience } \\
\text { and their health outcomes }\end{array}$ & $\begin{array}{l}\text { Aged care facility (ACF), } \\
\text { LTC }\end{array}$ & Retrospective & Donabedian model & $\begin{array}{l}\text { The studies indicate that the NPs with } \\
\text { their advanced clinical skills and } \\
\text { prescribing rights, were able to deliver } \\
\text { a range of timely health services within } \\
\text { the ACF in the absence of a PCP. This } \\
\text { resulted in reduced hospitalization and } \\
\text { managing of care of residents at the } \\
\text { facility }\end{array}$ \\
\hline Reidt & $\begin{array}{l}\text { To study an interprofessional } \\
\text { collaborative practice model } \\
\text { aimed to improve discharge } \\
\text { management from the } \\
\text { transitional care unit of the } \\
\text { skilled nursing facility (SNF) to } \\
\text { home. The model includes a } \\
\text { geriatrician, nurse practitioner } \\
\text { and a pharmacist }\end{array}$ & SNF, LTC & $\begin{array}{l}\text { Prospective, } \\
\text { Retrospective }\end{array}$ & $\begin{array}{l}\text { Comparison of intervention and } \\
\text { control groups }\end{array}$ & $\begin{array}{l}\text { This study suggests that collaboration } \\
\text { among a geriatrician, nurse } \\
\text { practitioner, and pharmacist may be an } \\
\text { effective means of decreasing } \\
\text { hospitalizations and ED visits within } \\
30 \text { days after SNF discharge }\end{array}$ \\
\hline
\end{tabular}


Table 1. Cont

\begin{tabular}{|c|c|c|c|c|c|}
\hline $\begin{array}{l}\text { Author Last } \\
\text { Name }\end{array}$ & Aim & Sample/Settings & Method & Assessment Tool & Key Findings \\
\hline Arendts & $\begin{array}{l}\text { To enhance quality of life and } \\
\text { reducing hospitalizations for } \\
\text { people living in residential aged } \\
\text { care facilities (RACF) }\end{array}$ & $\begin{array}{l}\text { Six facilities ( } 352 \text { beds } \\
\text { each) were included, } \\
\text { RACF, LTC }\end{array}$ & $\begin{array}{l}\text { Prospective, } \\
\text { Retrospective, } \\
\text { quasi-experimental. } \\
\text { A cluster controlled } \\
\text { clinical trial of nurse } \\
\text { practitioner care in } \\
\text { RACF. Six facilities } \\
\text { were included: three } \\
\text { randomly allocated } \\
\text { to intervention } \\
\text { where nurse } \\
\text { practitioners } \\
\text { working with } \\
\text { general practitioners } \\
\text { and using a best } \\
\text { practice guide were } \\
\text { responsible for care, } \\
\text { and three control }\end{array}$ & $\begin{array}{l}\text { Modified Barthel Index (MBI), } \\
\text { Psychogeriatric Assessment Scale } \\
\text { (PAS) assessments }\end{array}$ & $\begin{array}{l}\text { Nurse practitioner care coordination } \\
\text { resulted in no statistically significant } \\
\text { change in rates of ED transfer or health } \\
\text { care utilization, but better maintained } \\
\text { resident quality of life }\end{array}$ \\
\hline
\end{tabular}


Table 2. Matrices Showing Theme Occurrence.

\begin{tabular}{|c|c|c|c|}
\hline Facilitators & Occurrences & Sum & $\%$ \\
\hline $\begin{array}{l}\text { Decreased } \\
\text { hospitalizations }\end{array}$ & $7,8,9,10,11^{*}, 12^{*}, 13,14^{*}, 15^{*}, 16,17^{*}, 18,19,20^{*}, 21,22,23^{*}, 24,25,26,27^{*}$ & 37 & $27.21 \%$ \\
\hline $\begin{array}{l}\text { Improved health } \\
\text { outcomes }\end{array}$ & $7,9^{*}, 12,14,20^{*}, 21^{*}, 23^{*}, 24^{*}, 26,28^{*}, 29^{*}, 30,31$ & 27 & $19.85 \%$ \\
\hline Improved quality of care & $8^{*}, 13,14^{*}, 18,19,20^{*}, 23^{*}, 24,26,27,28^{*}, 31,33$ & 26 & $19.12 \%$ \\
\hline $\begin{array}{l}\text { Increased access to } \\
\text { healthcare }\end{array}$ & $18,20,23,24^{*}, 25,30,31^{*}, 33,34^{*}$ & 14 & $10.29 \%$ \\
\hline $\begin{array}{l}\text { Unrestrictive or least } \\
\text { restrictive scope of } \\
\text { practice for NPs }\end{array}$ & $10,14,16,17,31,32,33,34,35,36^{*}$ & 10 & $7.35 \%$ \\
\hline Reduced healthcare costs & $7,8,9^{*}, 12,14,23,30$ & 9 & $6.62 \%$ \\
\hline $\begin{array}{l}\text { Multidisciplinary } \\
\text { approach }\end{array}$ & $21^{*}, 25,29,32$ & 5 & $3.68 \%$ \\
\hline Improved end of life care & $16^{*}$ & 3 & $2.21 \%$ \\
\hline $\begin{array}{l}\text { Patient and family } \\
\text { education }\end{array}$ & $13,20^{*}$ & 3 & $2.21 \%$ \\
\hline \multirow[t]{2}{*}{$\begin{array}{l}\text { Improved patient and } \\
\text { family satisfaction }\end{array}$} & 19,32 & 2 & $1.47 \%$ \\
\hline & & 136 & \\
\hline Barriers & Occurrences & Sum & $\%$ \\
\hline $\begin{array}{l}\text { Restrictive scope of } \\
\text { practice for NPs }\end{array}$ & $9,14,16,20,23,24,31^{*}, 32^{*}, 34,35,36$ & 13 & $28.89 \%$ \\
\hline Poor quality of care & $13^{*}, 19,20,22,27,28^{*}$ & 11 & $24.44 \%$ \\
\hline $\begin{array}{l}\text { Lack of access to } \\
\text { healthcare }\end{array}$ & $17,20,22^{*}, 27,29$ & 7 & $15.56 \%$ \\
\hline Inadequate staffing & $8,10,17,23,28,33$ & 6 & $13.33 \%$ \\
\hline $\begin{array}{l}\text { Decreased patient } \\
\text { satisfaction }\end{array}$ & $17,23,29$ & 3 & $6.67 \%$ \\
\hline Poor decision making & $18^{*}$ & 2 & $4.44 \%$ \\
\hline $\begin{array}{l}\text { Increased } \\
\text { hospitalizations }\end{array}$ & 19 & 1 & $2.22 \%$ \\
\hline $\begin{array}{l}\text { Increased healthcare } \\
\text { costs }\end{array}$ & 19 & 1 & $2.22 \%$ \\
\hline \multirow[t]{2}{*}{ Poor communication } & 36 & 1 & $2.22 \%$ \\
\hline & & 45 & \\
\hline
\end{tabular}

\section{Results}

A total of 30 articles published over a fifteen-year period, 2004 through 2019, were reviewed. All the articles reviewed discussed the impact nurse practitioners had in reducing hospitalizations and improving quality outcomes in the long-term care setting. Themes were identified and sorted into positive facilitators and negative barriers impacting nurse practitioners and patient care with regard to hospital admissions or readmission to hospitals for residents of long-term care facilities. Nineteen themes were identified, ten of which were facilitators, nine of which were barriers.

\subsection{Facilitators}

Ten facilitator themes were identified. Their occurrence, frequency sum, and percent frequency are shown in Table 2. The positive facilitator theme presence of NPs decreasing hospitalizations was mentioned in 37 of 136 occurrences, or $27.21 \%$ [7-27]. The presence of NPs also improved health outcomes was mentioned in 27 of 136 occurrences of facilitator themes, or $19.85 \%$ [7,9,12,14,20,21,23,24,26,28-31]. 
Improved patient and family satisfaction were mentioned in 2 of 136 occurrences of facilitator themes, or $1.47 \%$ [19,32]. Improved quality of care was mentioned in 26 of 136 occurrences of facilitator themes, or $19.12 \%[8,13,14,18-20,23,24,26-28,31,33]$. Improved end-of-life care was mentioned in 3 of 136 occurrences of facilitator themes, or $2.21 \%$ [16]. Additional facilitator themes identified during the review of the articles were as follows. Increased access to healthcare was mentioned in 14 of 136 occurrences of facilitator themes, or $10.29 \%$ [18,20,23-25,30,32-34]. Patient and family education were mentioned in 3 of 136 occurrences of facilitator themes, 2.21\% [13,20]. Multidisciplinary approach was mentioned in 5 of 136 occurrences of facilitator themes, or 3.68\% [21,25,29,32]. Reduced healthcare costs were mentioned in 9 of 136 occurrences of facilitator themes, or $6.62 \%$ [7-9,12,14,23,30]. Unrestrictive or least restrictive scope of practice for NPs was mentioned in 10 of 136 occurrences of facilitator themes, $7.35 \%[10,14,16,17,31-36]$.

Successful strategies in which NPs decreased hospitalizations included NP-led advance care planning, medication reconciliation interventions, employing full-time NP at skilled nursing facilities, NPs providing patient-centered care, increased access and availability of full-practice NPs, staff coaching and education, and on-site assessments [7,8,10-13,17,20,22-26].

Many of the articles reviewed indicated NPs were a valuable resource to prevent unnecessary hospitalizations and clearly impacted a reduction in emergency room visits and hospitalizations particularly among the frail elderly and seniors [7-18,20-27]. Elderly patients managed by NPs had a lower hospital length of stay, were provided person-centered care, and a significant difference was found in the relationship between the number of NP discussions with patients about care and the number of hospitalizations [7,20,23]. Skilled nursing facilities implementing an NP-led medication reconciliation intervention lead to reduction in all-cause hospital readmissions [8].

Improved health outcomes were associated with NP interventions and care, as indicated in $19.85 \%$ of occurrences $[7-9,12-14,16-21,23,24,27-30,32]$. NPs, as primary care providers, advocated for patients and families, improved chronic disease management and care planning, and reduced depressive symptoms in patients they treated [20,24,29]. Time NPs spent in nursing activities were highly correlated with improved health outcomes, as well $[9,24,28]$. For example, when NPs provided only two hours on average per month for six months, elders in their care were able to improve function with a hip fracture and increase their activities of daily living [24]. Patients transferring between inpatient hospitals and nursing facilities had improved outcomes when a full-time NP was on staff [28]. Additionally, patients seen by NPs within four days of admission to a long-term care facility had lower mortality and costs during the following month [9]. Once residents and their families experienced NP care, patient satisfaction and family and patient requests for NP services improved [19,32].

Improved quality of care was mentioned in 23 of 132 occurrences $(19.21 \%)$ of facilitator themes encompassing the improvement of quality measures, providing education to staff and assisting with clinical care, and involvement with quality improvement initiatives, e.g., the Intervention to Reduce Acute Care Transfers (INTERACT) [7-9,12-14,16-21,23,24,27-30,32,33]. One qualitative study reviewed provided insights to person-centered care from the residents' and family perspectives [23]. Relationships between the patients, families, and the NP were fundamental to the experience of life within the community of a long-term care home [23]. Not only was the quality of care improved by having the NPs work in these settings, but also both residents and family members expressed how they valued NP's sharing information with them and involving them in decision-making related to care [23].

When NPs were utilized, patients experienced increased access to healthcare, patient and family education, and a multidisciplinary approach [13,18,20,21,23-25,29,30,32,33]. Increased access to healthcare was mentioned in 14 of 132 occurrences (10.29\%) of facilitator themes [18,20,23-25,30,32-34]. Failures in the traditional process of primary care provider referrals negatively impacted quality outcomes of resident care [32]. When utilized, NP services adequately filled the gap [32]. In fact, in long-term care, NPs often played the lead role as primary care providers [34]. Their ability to communicate and collaborate with other healthcare professionals, patients, and their families about their chronic illnesses, disease trajectories, and their goals of care positively impacted clinical 
outcomes [20,21]. Additionally, NPs provided staff education to address underlying causes of falls and other medical conditions such as dehydration, muscle weakness, and medication side effects further improving clinical outcomes [13].

The theme of reduced healthcare costs was mentioned in 9 of 132 factors of facilitation (6.62\%). NPs reduced healthcare costs, lowering Medicare expenditures per patient by reducing emergency room visits and providing cost-effective care $[7-9,11,12,14,23,30]$. One study reviewed indicated that when integrating NPs to care, patient savings of $\$ 13,000$ were seen when hospital charges were compared between the cohorts [7]. Additionally, NPs increased revenue by keeping the patients within the long-term care setting for treatment [8].

The theme NPs working in an unrestrictive or least restrictive scope of practice occurred in 10 of 136 occurrences $(7.35 \%)$. Those NPs working at this capacity were well positioned to promote high quality care, multidisciplinary collaboration, communication, education, leadership, advocacy, research, and evidence-informed practice $[10,14,16,17,31,33,34,36]$. Unrestricted scope of practice for NPs improved health outcomes and reduced the costs [34]. To ensure successful NP practice, both state and organizational policies should be taken into consideration [36].

NPs positively impacted end-of-life care for residents in nursing home facilities [16]. Themes of improving end-of-life care were mentioned in $2.21 \%$ of the occurrences. With the advent of NPs with palliative care expertise, end-of-life nursing home care was improved by reducing acute care use and potentially burdensome care transitions for residents with advanced illness [16].

\subsection{Barriers}

Nine barrier themes were identified. Their occurrence, frequency sum, and percent frequency are shown in Table 2. The negative barrier theme most often mentioned was the restrictive scope of practice for NPs, identified in 13 of 45 occurrences (28.89\%) reviewed [9,14,16,20,23,24,31,32,34-36]. Lack of policy and funding, Medicare regulations, state regulatory constraints, prohibited billing for visits, and no authority to write or change orders were all contributors to restrictive scope of practice for NPs $[9,23,24,32,34,35]$. These restrictions required direct or indirect supervision from physicians for NPs, as well [31]. Changes in Medicare regulations are needed to facilitate improved utilization of NP services in long term care facilities [14].

Poor quality of care was identified as another barrier in 11 of 45 occurrences $(24.44 \%)$ [13,19,20,22,27,28]. In some cases, the use of NPs as primary providers caused delays in care of the resident and outcomes, however, these outcomes were not significant when compared to physician outcomes [28]. Poor discharge protocols from hospitals to nursing facilities caused issues with rehospitalization before residents could be seen by NPs $[13,28]$. Further issues with discharge and admission to nursing facilities caused approximately $27.9 \%$ of residents to not be seen by physicians or NPs before hospital readmission [28]. This contributed to increased mortality rates of residents due to slowed time from admission to treatment by NPs [19]. Many facilities used objective tools at admission to assess acuity of residents and these tools were not used appropriately, thus increasing time to NP intervention [20]. There was also some evidence of increased mortality rates [19] and a lack of improvement of the care being given by NPs [27], however these were not more significant than care provided by physicians.

Lack of access to healthcare was identified as another barrier to the use of NPs in 7 of 45 occurrences $(15.56 \%)[17,20,22,23,27,29]$. Unfortunately, choices made by families or residents often resulted in discharges to hospital instead of care being provided by NPs [29]. Conversely, there was also a lack of available NPs in many areas to provide care to residents [17]. Both this lack of available staff and lack of specifically trained NPs in behavioral interventions resulted in a lack of proper behavioral health care being provided $[17,20]$. Nursing facility residents have a $25 \%$ greater chance at acquiring chronic conditions [22]. Of these chronic conditions, there are five that account for approximately $80 \%$ of hospital admissions/readmissions which are difficult for any provider to manage [22]. There is a perception that NPs are not aggressive enough in encouraging rehabilitation [27], however it should be 
noted that this is relatively dictated by resident payor status to begin with. When NPs were tasked with covering too many nursing facilities, this caused a decrease in the level of care [23].

Inadequate staffing was also identified as a concern surrounding the use of NPs in 6 of 45 occurrences (13.33\%) [8,10,17,23,28,33]. Many long-term care facilities operated with limited resources and inadequate staffing further increasing the barriers NPs faced $[8,10,17,23,28,33]$. Many long-term care facilities do not have the capacity or resources to have an available NP to perform a stabilization and medication reconciliation visit upon each admission, for example [8]. Additionally, many transfers occurred on evening and night shifts which had lower staffing levels [17].

Patient and family preferences due to decreased patient satisfaction were also identified, occurring in $6.67 \%$ of the occurrences. Both were identified as barriers to NPs' impact to reduce hospitalizations and improve quality outcomes in the long-term care setting $[17,23,29]$. Residents may prefer to get treatment and/or insist to go to the hospital, for example, instead of receive care from the NP at the long-term care facility $[17,23]$. It is probable that in circumstances where acute illness or injury arise, the preference for the transfer of patients predominates even when alternatives exist [29].

Poor decision making [18*] (4.44\%), increased hospitalizations [19] $(2.22 \%)$, increased healthcare costs [19] (2.22\%), and poor communication [36] (2.22\%) were also identified as barriers. Poor practices by the discharging hospitals resulting in early rehospitalizations occurred many times before patients could be evaluated by an NP [19]. For those patients admitted to the long-term facility, many were transferred back to the hospital within 30 days of admission due to functional decline, suspected respiratory infections, and new urinary tract infections [18]. Hospitalizations from these conditions could have been potentially avoided should an NP have provided care and treatment [18]. For those communities utilizing NP services, NPs often covered a high number of residents over multiple homes negatively affecting the quality of care and increasing patient transfers to hospitals [36]. Management changes, i.e., administrators, directors of nursing, and other key personnel may also negatively impact the already existing deficiencies in NPs' perceptions of their relationship with administration and how their role is understood and valued in their organizations [18,19].

\section{Discussion}

The study findings indicate that NPs play an important role in improving health outcomes, quality of care, and reducing hospitalizations in a long-term care setting. The facilitators of NP roles outweigh the barriers in the long-term care setting. State quality initiatives show clear benefits of the use of full-time advanced practice registered nurses. These benefits are in quality improvement activities, increased end-of-life decision making, and improvements in the use of health information technology. Benefits of the use of systematic care tracking tools such as the use of the Interventions to Reduce Acute Care Transfers (INTERACT) were also noted. Avoidable hospitalizations actually increased under the use of NPs by $7 \%$ overall, however unavoidable hospitalizations decreased by an impressive $17 \%$. The use of NPs has allowed a much more directed examination of care delivery systems, and measures to be put into place to correct any deficiencies in this area. The use of NPs to review medications and to reconcile them resulted in a 5.7\% decrease in unnecessary hospitalizations.

Overall, the use of NPs reduces acute care usage, hospitalizations, and it eases care transitions when they do occur. NPs bring an increased ability to build relationships with families and residents, and to help both populations to better understand the care and to make well-informed choices. These are all significant areas which contribute to an increased quality of care which occurs when a NP is involved. There is a marked difference in health outcomes and hospitalizations in states with high levels of NP involvement as opposed to states with lower involvement. The utilization of NPs in a long-term care setting should be encouraged to improve access to care and to enhance quality of care. 


\section{Limitations}

The authors identified limitations to this review. Our search strategy relied on a 4-string Boolean phrase and germane topics assigned by authors and may have missed instruments that are relevant to the role of an NP in reducing hospitalizations and improving quality outcomes in long-term care settings but were not identified. Many of the articles reviewed had small sample sizes which limited the generalizability of the individual study results. Additionally, because each long-term care facility had different dynamics, the results of this review may not be generalizable. Many long-term care facilities do not have the capacity or resources to have an available NP. Only English language articles were included in the review, so we did not capture the perspectives of people from different backgrounds.

\section{Future Research}

An unexpected finding during the systematic review was the restrictive state and federal regulations regarding NPs. Future research and review of the different restrictions could assist with enabling NPs to practice more freely, improving quality outcomes and decreasing hospitalizations. More research using larger samples in the area of NP impact on long-term care quality outcomes and decreasing hospitalizations would increase the generalizability of study results. Future studies should address NPs' impact on decreased hospitalizations and improved quality outcomes other than those in primarily English-speaking regions. Further areas of future research may also include the impact of NPs on staffing shortages surrounding physician providers. The inclusion of NPs could also significantly change the administration of medical care in nursing facilities. However, the role of the NP could also prove to be challenging as well when it comes to the provision of that care and the differences in states with full practice rights for NPs and those without.

Author Contributions: Conceptualization, U.P., B.P., E.S. and M.M.; methodology, M.M., and R.M.; software, M.M.; validation, U.P., B.P., M.M., and R.M.; formal analysis, U.P., B.P., E.S., M.M. and R.M.; investigation, U.P., B.P., E.S.; resources, M.M.; data curation, U.P., B.P.; writing-original draft preparation, U.P., B.P., E.S.; writing-review and editing, U.P., B.P., M.M. and R.M.; visualization, U.P., B.P.; supervision, U.P., B.P., M.M.; project administration, U.P. All authors have read and agreed to the published version of the manuscript.

Funding: This research received no external funding.

Conflicts of Interest: The authors declare no conflict of interest.

\section{References}

1. Bakerjian, D. Care of Nursing Home Residents by Advance Practice Nurses. Res. Gerontol. Nurs. 2008, 1, 177-185. [PubMed]

2. Ness, J.; Ahmed, A.; Aronow, W. Demographics and Payment Characteristics of Nursing Home Residents in the United States: A 23-Year Trend Introduction article. J. Gerontol. Med Sci. 2009, 59, 1213-1217. [CrossRef] [PubMed]

3. Murray, L.; Laditka, S. Care Transitions by Older Adults from Nursing Homes to Hospitals: Implications for Long-Term Care Practice, Geriatrics Education, and Research. J. Am. Med Dir. Assoc. 2010, 11, 231-238. [CrossRef] [PubMed]

4. Mor, V.; Intrator, A.; Feng, Z.; Grabowski, D. The Revolving Door of Rehospitalization from Skilled Nursing Facilities. Health Aff. 2010, 29, 57-64. [CrossRef]

5. Naylor, M.; Kurtzman, E.; Pauly, M. Transitions of Elders between Long-Term Care and Hospitals. Policy Politics Nurs. Pract. 2009, 10, 187-194. [CrossRef]

6. Kruse, C.S. Writing a Systematic Review for Publication in a Health-Related Degree Program. JMIR Res. Protoc. 2019, 8, e15490. [CrossRef]

7. Bethea, A.; Samanta, D.; White, T.; Payne, N.; Hardway, J. Nurse Practitioners Role in Improving Service for Elderly Trauma Patients. J. Trauma Nurs. 2019, 26, 174-179. [CrossRef]

8. Anderson, R.; Ferguson, R. A nurse practitioner-led medication reconciliation process to reduce hospital readmissions from a skilled nursing facility. J. Am. Assoc. Nurse Pract. 2019, 32, 160-167. [CrossRef] 
9. Rantz, M.J.; Popejoy, L.; Vogelsmeier, A.; Galambos, C.; Alexander, G.; Flesner, M.; Murray, C.; Crecelius, C. Ge, B. Impact of Advanced Practice Registered Nurses on Quality Measures: The Missouri Quality Initiative Experience. J. Am. Med Dir. Assoc. 2018, 19, 541-550. [CrossRef]

10. Ersek, M.; Hickman, S.; Thomas, A.; Bernard, B.; Unroe, K. Stakeholder Perspectives on the OPTIMISTIC Project. Gerontologist 2018, 58, 1177-1187. [CrossRef]

11. Cole, M.S. Case study Realizing the Value of Nurse Practitioners in Long Term Care. Nurs. Leadersh. 2017, 3, 39-44. [CrossRef]

12. Ingber, M.J.; Zhanlian, F.; Khatutsky, G.; Wang, J.M.; Bercaw, L.E. Initiative to Reduce Avoidable Hospitalizations Among Nursing Facility Residents Shows Promising Results. Health Aff. 2017, 36, 441-450. [CrossRef]

13. Rantz, M.; Popejoy, L.; Vogelsmeir, A.; Galambos, C.; Alexander, G.; Flesner, M.; Crecelius, C.; Ge, B.; Petroski, G. Successfully Reducing Hospitalizations of Nursing Home Residents: Results of the Missouri Quality Initiative. JAMDA 2017, 18, 960-966.

14. Birtley, N.; Flenser, M.; Crecelius, C.; Murray, C. Call to action APRNs in US nursing homes to improve care and reduce costs. Nurs. Outlook 2017, 65, 689-696.

15. Hullick, C.; Conway, J.; Higgins, I.; Hewitt, J.; Dilworth, S.; Holliday, E.; Attia, J. Emergency department transfers and hospital admissions from residential aged care facilities a controlled pre-post design study. Bmc Geriatr. 2016, 16, 1-10. [CrossRef]

16. Miller, S.C.; Lima, J.C.; Intrator, O.; Martin, E.; Bull, J.; Hanson, L.C. Palliative Care Consultations in Nursing Homes and Reductions in Acute Care Use and Potentially Burdensome End-of-Life Transitions. JAGS 2016, 64, 2280-2287. [CrossRef]

17. Ouslander, J.; Naharci, I.; Engstrom, G.; Shutes, J.; Wolf, D.; Alpert, G.; Rojido, C.; Tappen, R.; Newman, D. Root cause analysis of Transfers of SNF patients to Acute Hospitals. JAMBDA 2016, 17, 256-262.

18. Ouslander, J.; Naharci, I.; Engstrom, G.; Shutes, J.; Wolf, D.; Alpert, G.; Rojido, C.; Tappen, R.; Newman, D. Hospital Transfers of Skilled Nursing Facility (SNF) Patients Within 48 Hours and 30 Days After SNF Admission. JAMBDA 2016, 17, 839-845. [CrossRef]

19. Meunier, M.; Brant, J.; Audet, S.; Dickerson, D.; Gransbery, K.; Clemins, E. Life after PACE (Program of All-Inclusive Care for the Elderly): A retrospective/prospective, qualitative analysis of the impact of closing a nurse practitioner centered PACE site. J. Am. Assoc. Nurse Pract. 2016, 28, 596-603. [CrossRef]

20. Mullaney, S.; Devereaux Melillo, K.; Lee, A.J.; MacArthur, R. The association of nurse practitioners' mortality risk assessments and advance care planning discussions on nursing home. J. Am. Assoc. Nurse Pract. 2016, 28, 304-310.

21. Ordonez, M.; Hain, D. Healthy Transitions from Hospital to Skilled Nursing Facility Post-CABG. J. Nurs. Pract. Appl. Rev. Res. 2014, 4, 123-134.

22. Segal, M.; Rollins, E.; Hodges, K.; Roozeboom, M. Medicare Medicaid Eligible Beneficiaries and Potentially Avoidable Hospitalizations. MMRR 2014, 4, 1-13. [CrossRef]

23. Ploeg, J.; Kassalainen, S.; McAiney, C.; Martin-Misener, R.; Donald, F.; Wickson-Griffiths, A.; Carter, N.; Sangster-Gormley, E.; Schindel Martin, L.; Brazil, K.; et al. Resident and family perceptions of the nurse practitioner role in long term care settings: A qualitative descriptive study. BMC Nurs. 2013, 12, 24. [CrossRef]

24. Krichbaum, K. GAPN Postacute Care Coordination Improves Hip Fracture Outcomes. West. J. Nurs. Res. 2007, 29, 523-544. [CrossRef]

25. Reidt, S.; Holtan, H.; Larson, T.; Thompson, B.; Kerzner, L.; Salvatore, T.; Adam, T. Interprofessional Collaboration to Improve Discharge from ED Visits. JAGS 2016, 64, 1895-1899. [CrossRef]

26. Rosenfeld, P.; Kobayashi, M.; Barber, P.; Mezey, M. Utilization of Nurse Practitioners in Long-Term Care: Findings and Implications of a National Survey. JAMDA 2004, 5, 9-15. [CrossRef]

27. Kane, R.L.; Flood, S.; Bershadsky, B.; Keckhafer, G. Effect of an Innovative Medicare Managed Care Program on the Quality of Care for Nursing Home Residents. Gerontologist 2004, 44, 95-103. [CrossRef]

28. Rykina, K.L.; Yuan, Y.; Teng, S.; Burke, R. Assessing First Visits by Physicians to Medicare Patients Discharged to Skilled Nursing Facilities. Health Aff. 2019, 4, 528-536. [CrossRef]

29. Arendts, G.; Deans, P.; O’Brien, K.; Etherton-Beer, C.; Howard, K.; Lewin, G.; Sim, M. A Clinical Trial of NP Care in Residential Aged Facilities. Arch. Gerontol. Geriatr. 2018, 77, 129-132. [CrossRef]

30. Kuo, Y.-F.; Loresto, F.; Rounds, L.; Goodwin, J. States with the Least Restrictive Regulations Experienced the Largest Increase in Patients Seen by Nurse Practitioners. Health Aff. 2013, 32, 1236-1243. [CrossRef] 
31. Oliver, G.; Pennington, L.; Revelle, S.; Rantz, M. Impact of NPs on health outcomes of Medicare and Medicaid patients. Nurse Outlook 2014, 62, 440-447. [CrossRef]

32. Dwyer, T.; Crasswell, A.; Rossi, D.; Holzberger, D. Evaluation of an aged care NP service quality of care within a resident aged care facility. Bmc Health Serv. Res. 2017, 17, 1-11. [CrossRef]

33. Kaasalainen, S.; Papaioannou, A.; Burgess, J.; Van Der Horst, M.L. Exploring the NP Role in Managing Fractures in Long Term Care. Clin. Nurs. Res. 2016, 24, 567-588. [CrossRef]

34. Yang, M.; Chang, C.-H.; Carmichael, D.; Oh, E.; Bynum, J. Who Is Providing the Predominant Care for Older Adults with Dementia? JAMDA 2016, 17, 802-806. [CrossRef]

35. Popejoy, L.; Vogelsmeir, A.; Alexander, G.; Gallambos, C.; Crecelius, C.; Ge, B.; Flesner, M.; Canada, K.; Rantz, M. Analyzing Hospital Transfers Using INTERACT Acute Care Transfer Tools: Lessons from MOQI. JAGS 2019, 67, 1953-1959. [CrossRef]

36. Poghosyan, L.; Shang, J.; Liu, J.; Poghosyan, H.; Liu, N.; Berkowitz, B. Nurse practitioners as primary care providers: Creating favorable practice environments in New York State and Massachusetts. Health Care Manag. Rev. 2015, 40, 46-55. [CrossRef]

(C) 2020 by the authors. Licensee MDPI, Basel, Switzerland. This article is an open access article distributed under the terms and conditions of the Creative Commons Attribution (CC BY) license (http://creativecommons.org/licenses/by/4.0/). 